\title{
乳児雨液の澱粉糖化力に関する研究 \\ Studies on the Saccharizing Power of the Suckling's Saliva against Starch
}

\author{
第 1 編 総漫元値（糖北）よb見なる乳児唾液糖化力に就いて \\ Part 1. The Saccharizing Power of the Saliva of Sucklings from \\ the viewpoint of Total Reduced Value
}

(昭和 29 年 7 月 1 日受理)

秋田 兔

(Tutomu Akita)

（本論次の要吕は第 8 回栄独食粗学会にて報告した）

第 1 潮 緒 言

乳児唾夜の激粉消化力に関寸る研究は古くから行わ れ，その出現時期に就いては Ibrahim $^{1)}$, Moll12) 等の報 告がり, 上昇に関しては Korowin?), Schlossman), Nicor $y^{-5}$ ， Davidson ${ }^{6}$ ，佐々木7)，俣野早等の業績がある。 又激粉添加の消化力に及ほす寸影響に就いては, Finizio9), Hensel ${ }^{10}$ 等の研究があり, 既に幾多の業績を見るか， 何机も液消化力を糊精化作用の面から観察している。 この測定法はョード反応の色調变化を利用するのであつ て, 变色に要する時閒を測定するか, 或いは Wohlgemuth $^{11)}$ 法等の如く变色に要した喠液量より判定するか の何れかを採用している。これ等の方法は研究者の主観 が加わり，又喠液を倍々に稀杓する関係上，消化単位とし て表わされる值か倍々に評価され，詳細なる消化力がわ かり難い憾みがある。侗上述の研究報告は例数が少なく， 重液消化力の如き著しい個人差のあるものでは，少数例 から消化力の一般的倾向を云々する事は無理である。

メアミラーセ醉素研究の著しい進歩にともない, 現在 では，1925 1930年頃発表された Kuhn ${ }^{12)}$ 及び Ohls. son ${ }^{13) の ~} \alpha-, \beta-$ アミラーゼの二醅素説が一般に認められ るに至り，睡液アミラーゼは性質上 $\alpha$ 型に属寸るものと 見做されている。 $\alpha$ 型の性質としては，主として液化， 糊精化作用を営む゙すのとされているか，糖化作用も行引 ので, 唾液消化力をしらべる場台は, 両作用面から観察 しなければ明らかな消化力はわからないのである。

そこで著者は乳览唾液消化力に就いて，㴬粉をどの位 糖化する能力があるものか, 又月令の進むにつれて如何 なる糖化力を示するのか, 糖化力作用面から上述の如き 過去の研究の不備を補5目的で本研究を企図したもので ある。
第 2 章 乳児唾液糖化力の测定に就いて

乳览唾液糖化力の観察に先だち，糖化力測定に哭し予 備然験の意味に於いて，次の楛点に就いて実験を試みた ので以下述べる。

(1) 睡液アミラーゼの活性度表示方法に就いて

(2) 唾夜採取方法に就いて

(3) 乳览唾夜糖化力の力価標準に就いて

(1) 嘈液アミラーゼの活性度表示方法に就いて

唾夜を瑖粉に作用させると，デキストリン，麦芽糖， 葡萄䊰か生成されてくる事は既に古くから知られている が，か样に種々の邆元性物質か生ずる場合は，その糖化 能力を簡単な方法によつて正確に表す事は甚だすつかし い。従つて喠液アミラーゼの活性度表示方法に就いては 種々な方法が考察されているが，一般によく使用せられ るのは Willstätter ${ }^{14)}$ 等のアミラーゼ単位によつて表す 方法である。

この方法は唾碓アミラーゼが应期にに於いて一分子 反応に従 5ものと見做して，その反応速度怚数からアミ ラーゼの活性度を測定するのである。著者もこの方法を 用いて活性度を表示しょ5と考え実験に着手したのであ るか，種々疑義を抱くに至り遂にこの方法による活性度 表示を断念するに至つた。以下その理由に就いて述べよ 5と思5。

一般に酥素作用が一分子反応従 5 時，その速度と基 質濃度との関保から $\mathrm{K}=\frac{1}{\mathrm{t}} \quad \log \frac{\mathrm{a}}{\mathrm{a}-\mathrm{x}}$ なる式か成立 する。この場合一般には, $\mathrm{a}$ は基質の最初の澄度, $\mathrm{x}$ は $\mathrm{t}$ 時間作用後の基質の消费量として計算されるのである が, Willstátter ${ }^{14)}$ 等は膵嗒アミラーゼに就いて研究し， 粉に作用させた場合，作用初期に於いて反应速度恒数 （K）か治んど一定に保たれ，而もその值か䤃素に比 
例する事を発見し一分子反応に伦5性質を認め，上式の $\mathrm{a}$ 值をアミラーゼにより澱粉が完全に麦芽糖に分解した 時の極大加水分解度を以つて表し, $\mathrm{x}$ : $\mathrm{t}$ 時間後の麦芽 糖生成量を以つて示し反応速度恒数を求めている。 この場合, 彼等は $\mathrm{a}$ 值を経験的に $75 \%$ として決めて いるのであるが，果してかよ5にして决められたa值が 適当であるか否種々疑間が持たれるのである。

即ち唾液を瑖粉に作用させて見ると第 1 四の如くなる が，（笑験方法；第3章参照）此図を見て明らかな如 く, 楉化曲線屈曲後に於いても向分解が僅かずつではあ るが行われているように思われるので，どの点を極大加 水分解点として取るべきか，容易にa 值は決められない ものと考えられる。

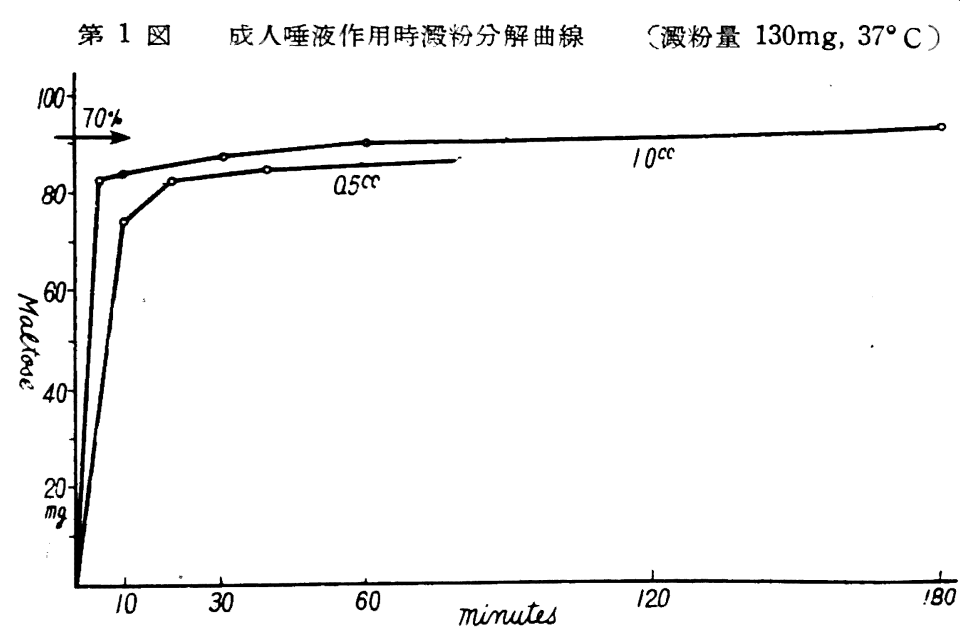

由に就いて述べたが，著者は次のよ5な方法で、值を導 き出し得ないだろらかと考え然験を試みた。

即ち反応初期に於いて一分子反応が成立するとすれ ば，その時間内に於いては，K及び、は一定でなければ ならない。従つて反応初期に於いて $\mathrm{t}$ 及び $2 \mathrm{t}$ 時間の生 成麦芽糖量を $\mathrm{x} 及 ひ ゙ \mathrm{x}^{\prime}$ とするならば，次の式が成立せ ねばならない。

$$
\begin{aligned}
& K=\frac{1}{t} \quad \log \frac{a}{a-x} \cdots \cdots \cdot(1) \\
& K-\frac{1}{t} \log \frac{a}{a-x^{\prime}}, \cdots \cdots \cdots(2)
\end{aligned}
$$

(1)(2)上り $\mathrm{a}=\frac{\mathrm{x}^{2}}{2 \mathrm{x}-\mathrm{x}^{\prime}}$ か導き出される。又一方酵素

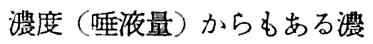
度に於ける分解度と, その 2 倍の濃度に於忛る分解度を比 較することによつて同樣な式 が成立しな汁ればならない。 そこで反応初期に於いて一分 子反応が成立するならば, a 値は上式より一定の値が導き 出さるべきである。

この事を検討する為, 唾夜 量 $0.2 \mathrm{cc}, 0.1 \mathrm{cc}$ を $130 \mathrm{mg}$ の 汯粉に作用させ（实験方法, 第 3 章参照) 第 1 表の如き成 績を得た。
捶液アミラーゼに就いては, Euler ${ }^{15)}$, Myrbäck ${ }^{16)}$ 等 の業績があるが，彼等も経験的にa 值を $70 \%$ と決めて 反応速度恒数を求めている。毁ち Euler は $1 \mathrm{~g}$ の澱粉 に $2 \mathrm{cc}$ の重液を作用させ，90分值を以つて $\mathrm{a}$ 值を決定 しているか，長時間作用の成績が図示されていないの で, 恰かも70\%の分解以後停止したかの如く感ぜられ るが実際は第 1 図の成績の上5に, 時間の経過と共に僅 かす゚つではあるが分解か行われている樣な糖化曲線を示 す。勿論 Euler は糖化作用の経続を認め"Nachverzuckerung” と称し, この現象は葡萄糖の混合反応か生じ て来るからであろらと解积している。たとえこの現象か 葡萄糖の混合反応であつてす, か上5に経験的にa 值を 決める場合は, 酵素丧度は勿論, 使用激粉の製品及び種 類によつて, 糖化曲線の傾向も变つてくるものと思われ るので, $\mathrm{a}$ 值の理論的襄つけのない限り垁験者にとつて 極大加水分解点を決める事はむつかしい問題だと考え る。

以上 $\mathrm{a}$ 值を糖化曲線から経験的に決める事の困難な理
第 1 表 成人唾液 $0.2 \mathrm{cc}, 0.1 \mathrm{cc}$ 作用時の初期反 応に於ける生成麦芽糖量

\begin{tabular}{|c|c|c|c|}
\hline 作用時 & 液量 & $\begin{array}{l}\text { (a) } \\
0.2 \mathrm{cc}\end{array}$ & $\begin{array}{l}\text { (b) } \\
0.1 \mathrm{cc}\end{array}$ \\
\hline (A) & 2分 & $\underset{20.55}{\mathrm{mg}}$ & $\underset{10.26}{\mathrm{mg}}$ \\
\hline (B) & 4分 & 35.16 & 20.55 \\
\hline (C) & 8分 & 47.40 & 34.20 \\
\hline (D) & 16分 & 60.60 & 47.42 \\
\hline (E) & 32分 & 65.40 & 59.25 \\
\hline
\end{tabular}

（揤粉量 $130 \mathrm{mg}, 37^{\circ} \mathrm{C}$ )

この成績から上式を用いて $\mathrm{a}$ 偡を計算すると第 2 表の 如くなる。 
第 2 表 第 1 表成䅡より計算された a 值

\begin{tabular}{|c|c|c|c|}
\hline & & $=\frac{x^{2}}{2 x-x^{\prime}}$ & \\
\hline$(A)(B) ょ り$ & 71.0 & & - \\
\hline$(b)(a) ょ \eta$ & - & & 67.8 \\
\hline$(B)(C) \perp \eta$ & 54.0 & i & 58.2 \\
\hline$(b)(a) ょ \eta$ & 67.8 & & 55.7 \\
\hline$(C)(D) ょ り$ & 65.6 & & 55.7 \\
\hline$(b)(a) ょ y$ & 55.7 & 1 & 65.7 \\
\hline$(\mathrm{D})(\mathrm{E})\llcorner\mathfrak{D}$ & 65.8 & & 63.3 \\
\hline$(b)(a)\llcorner\eta$ & 65.7 & 1 & 66.1 \\
\hline
\end{tabular}

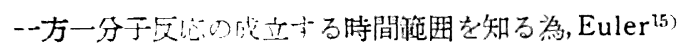
等の使用した $\mathrm{a}$ 侹 700 。から反応速度恒数を匴してみ ると第 3 表の値を示す。

第 4 表 唾液量 $0.2 \mathrm{cc}, 0.1 \mathrm{cc}$ 作用時の反応速 度狟数 (激的量 $130 \mathrm{mg}, 37^{\circ} \mathrm{C}$ )

\begin{tabular}{c|c|c}
\hline & $\mathrm{K}=\frac{\mathrm{l}}{\mathrm{t}}$ & $\log \frac{\mathrm{a}}{\mathrm{a}-\mathrm{x}}$ \\
\hline $\mathrm{t}$ & $0.2 \mathrm{cc}$ & $0.1 \mathrm{cc}$ \\
\hline 4 & 0.0554 & 0.0246 \\
8 & 0.0524 & 00276 \\
16 & 00398 & 0.0255 \\
32 & 0.0297 & 0.0199 \\
\hline
\end{tabular}

第 3 表の反応速度恒数（K值）を見るに，Kが一定し た値を示すのは, $0.2 \mathrm{cc}$ の場合は 4 分迄, $0.01 \mathrm{cc}$ の場合 は8 分迄であつて，この時間内に於いては一分子反応成 立が考えられるか，第 2 表の a 価を見るとその時間内に おいて一定した值を示さない。即ち一分子反応成立を仮 定してa値を求めたのであるから，a値が一定にならな い事は一分子反応の成立が認められない事になる。かよ 5な方法で一分子反応成立如何を論ずる事は正しいか否 かは別問題として，反心初期の短時間内においてての一 分子反応が成立しても，封間的な誤差が多分に入ると考 えられるので,このよ5な反応速度恒数を以てアミラー ゼ活性度を表示する方法には無理があると思われる。

恐らく喠液を濒粉に作用させた場合，反応初期におい、 ても複雑な混合反応が行われているのではないかと思 5。この点に就いては分別定量により第 2 編で検討する つるりである。

以上のよ5に根本的な間題である $\mathrm{a}$ 值に就いて疑問を もつたので, Willstätter ${ }^{14)}$ 等のアミラーゼ単位によつ て活性度を表示することに疑義をいだかざるを得なくな り, 著者は止むを得ず原始的でもあり力洒の比較に不便

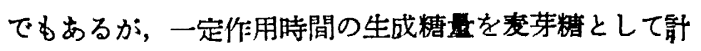
算し、これによつて糖化力を表示しょ 5 と考えた。

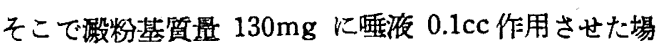
合, どの位の作用時間か妥当なるかをしらべる為, 成人

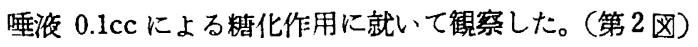

第 2 因成人唾液 $0.1 \mathrm{cc}$ 作用時の漖汾榶化曲線

(激粉量 $130 \mathrm{mg}, 37^{\circ} \mathrm{C}$ )

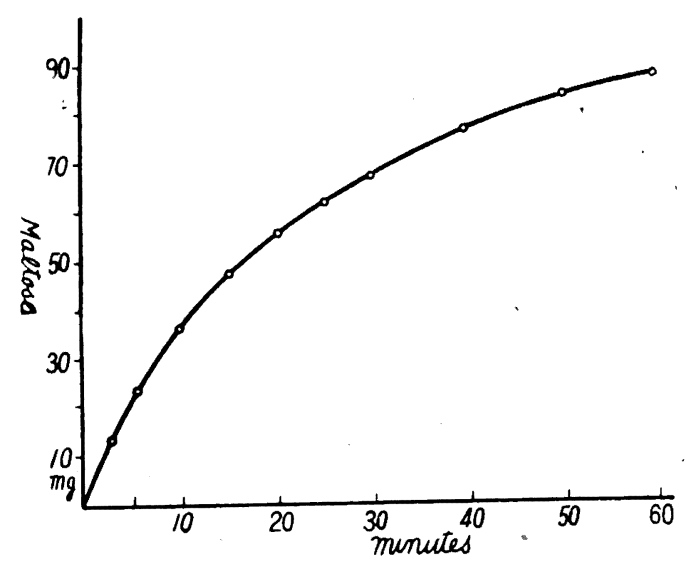

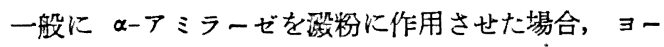
ド反応は䤂材料によつて少し異るが，通常 30〜45\% の分解率附近で消失するものと考えられている。而して このョード反応消失点は大体糖化曲線の屈曲に一致する あのと解されている に，ヨード反忘は20分值 (43.5\%) において橙色を示し 30 分值 $(50.8 \%)$ で消失している。侦つてこの頃の作用 時間が適当と思われるので，著者は噃液作用時間を30分 とし第 3 章の如き方法で生成楮量を测定した。

然しこのよ 5 な楉化力測定法は糖化力の強い場合, 糖 化曲線屈曲後において測定される事になり，力価比較の 際誤つた判定を下される缺点が多分にあるが，乳児唾液 糖化力と成人唾液糖化力と比較する笑験には大なる支障 はなかつたすのと思5。

\section{(2) 唾液採取方法に就いて}

喠液には能働性のものと非働性のものがあり, 前者は 耳下脉及び舌下, 顎下腺の一部から分泌され, 後者は舌 下, 顎下腺の一部から分泌されている。最近梅本 ${ }^{18)}$ 等は 分離探取器を考察して耳下腺の分離採取に成功し, 能働 性唾液のみの採取が可能になつたが，この分離採取器を 乳览に用いる事が困㘗なので，著者は混合整液に就いて 研究した。

採取器は Davidson 及び Hymanson' の考案した ものを参考にし第 3 図の如き採取器を使用した。 


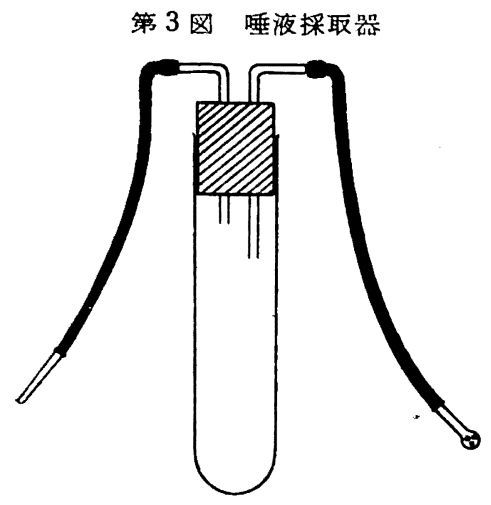

唾液を採取する埸合，採取する部位によつて如何程の 糖化力の差異が生ずるるのか，成人に就いて第3图の短 取器を用いてしらべてみた。

即ち自然流出睡液 (顔面を下方に向かせ流出するも の）と, 耳下腺開口部附近（頓内面と下顎选列間）及び

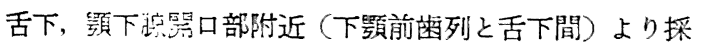
取した坓液と比較を試又第 4 及び第 5 表の成錆を得た。
第 4 表より明らかな如く, 自然流出挐液と耳下腺開口 部附近より拯取した唾液とは，何れの例に执いても，耳 下腺開口部附近より採取した唾液の方が糖化力が高く, 其の美は平均值 $5.59 \mathrm{mg}$ を示している。これは舌下, 顎 下腺唾液の非働性喠液の影響であると考えられる。又第 5 表を見るに, 舌下, 䫇下腺開口部附近より採取した唾 液は自然流出唾液よりあきらかに糖化力が低く, 平均值 $18.87 \mathrm{mg}$ の大なる美を生じ, 舌下, 顎下腺唾液の非衝性 唾夜の多い䗙を物語つている。

以上の成績かっら非働性喠液の混入程度により可成り影

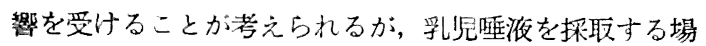
合は成人の埸合と異り, 分別して採取する事が困難なの で，湘定した結果，意外に低い値が出た場合は再度吟味 することにした。

乳児唾液を採取する场台は，舟親等に乳児を抱かして 軽く頭部を固定させ，拯叹者か上下口屡を手指にて毦く 開き探取器を耳下腺開口部附近に入れ採取した。又四乳 の混大を防ぐ為母乳投与後30分以上経過した事を確かめ 採取した，

第 4 表 成人に於ける自然流出膤液と耳下腺開口部附近探

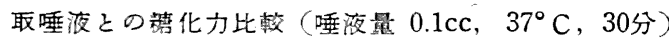

\begin{tabular}{|c|c|c|c|c|c|c|c|}
\hline No. & 氏 名 & 年令 & 徃 & 採取部位 & $\begin{array}{l}\text { 傏 化力 } \\
\text { (mg) }\end{array}$ & $A-B$ & $\begin{array}{c}\mathrm{A}-\mathrm{B} \\
\text { 平均 值 } \\
(\mathrm{mg})\end{array}$ \\
\hline 1 & H.A. & $3 \mathrm{j}$ & $\hat{\epsilon}$ & $\begin{array}{l}\mathrm{A} \\
\mathrm{B}\end{array}$ & $\begin{array}{l}58.85 \\
52.33\end{array}$ & 6.52 & \multirow{5}{*}{5.59} \\
\hline 2 & S.A. & $6 \mathrm{j}$ & $f$ & $\begin{array}{l}\mathrm{A} \\
\mathrm{B}\end{array}$ & $\begin{array}{l}65.51 \\
61.32\end{array}$ & 4.19 & \\
\hline 3 & J.U. & $15 \mathrm{j}$ & 웅 & $\begin{array}{l}A \\
B\end{array}$ & $\begin{array}{l}68.43 \\
64.20\end{array}$ & 4.23 & \\
\hline 4 & I.A. & $28 \mathrm{j}$ & $q$ & $\begin{array}{l}\mathrm{A} \\
\mathrm{B}\end{array}$ & $\begin{array}{l}72.21 \\
6532\end{array}$ & 6.89 & \\
\hline 5 & T.A. & $31 \mathrm{j}$ & $\hat{c}$ & $\begin{array}{l}A \\
B\end{array}$ & $\begin{array}{l}73.52 \\
67.38\end{array}$ & 6.14 & \\
\hline
\end{tabular}

採取部位 $\left\{\begin{array}{l}\mathrm{A} \cdots \cdots \cdot \text { 耳下腺開口部附近 } \\ \mathrm{B} \cdots \cdots \text { 自然流出 }\end{array}\right.$

第 5 表成人に於ける自然流出喠液と舌下, 影下腺開口部附

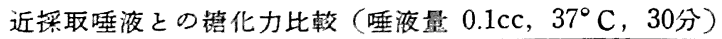

\begin{tabular}{|c|c|c|c|c|c|c|c|}
\hline No. & 氏 名 & 年令 & 性 & 採取部位 & $\begin{array}{l}\text { 侣 化 力 } \\
\text { (mg) }\end{array}$ & $-\mathrm{B}-\mathrm{A}$ & $\begin{array}{c}\mathrm{B}-\mathrm{A} \\
\text { 平 均 值 } \\
(\mathrm{mg})\end{array}$ \\
\hline 1 & S.A. & $6 \mathrm{j}$ & ㅇ & $\begin{array}{l}\mathrm{A} \\
\mathrm{B}\end{array}$ & $\begin{array}{l}49.43 \\
65.45\end{array}$ & 16.02 & \multirow{5}{*}{18.87} \\
\hline 2 & T.N. & $6 j$ & ㅇ & $\begin{array}{l}\mathrm{A} \\
\mathrm{B}\end{array}$ & $\begin{array}{l}54.52 \\
67.63 \\
\end{array}$ & 13.11 & \\
\hline 3 & J.U. & $15 j$ & f & $\begin{array}{l}\mathrm{A} \\
\mathrm{B}\end{array}$ & $\begin{array}{l}46.72 \\
67.00 \\
\end{array}$ & 20.28 & \\
\hline 4 & I.A. & $28 \mathrm{j}$ & $0^{\prime}$ & $\begin{array}{l}\mathrm{A} \\
\mathrm{B}\end{array}$ & $\begin{array}{l}45.86 \\
68.23 \\
\end{array}$ & 22.37 & \\
\hline 5 & T.A. & $31 \mathrm{j}$ & $\hat{\delta}$ & $\begin{array}{l}\mathrm{A} \\
\mathrm{B}\end{array}$ & $\begin{array}{l}45.80 \\
67.35 \\
\end{array}$ & 22.55 & \\
\hline
\end{tabular}




\section{（3）乳児䌚液榶化カの力価標準に就いて}

著者の用いた栯化力表示方法は，0.1cc 唾液を 30分你: 用させ生成する春芽糖量 ( m g ) によつて力洒を示してい るので, 例えば $0.1 \mathrm{cc}$ 唾液と $0.05 \mathrm{cc}$ 唾液の力洒を比較 する場合, 後者は前者の $1 / 2$ にならなければ適切な力洒 の表現法といい得ないが，著者の用いた糖化力表示では 明確に比較し難い。そこで測定された榶化力 $(\mathrm{mg})$ から 比較する場合，どの位の力価に相当するかを一見してわ

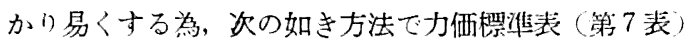
を作つた。跑ち成人唾液に就いて $0.1 \mathrm{cc}$ 唾液を30分作用 させた第合の糖化力（卷莱糖生成量）を 1 と古机ば，唾 液を倍に稀釈寸ることにより楉化力も $1 / 2 \sim 1 / 16$ となつ てくるので，測定された榶化力をこの表と照合すれば $0.1 \mathrm{cc}$ 唾液の糖化力を 1 とした場合，どの位の稀啝唾液 に相当する力価である事かかかる。又榶化力には個人美 があるので $0.1 \mathrm{cc}$ 唾液を作用させても各人によつて糖化

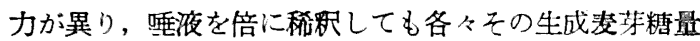
が違うので， $0.1 \mathrm{cc}$ 唾液糖化力を 1 としても各々の場合 によつてその樏準楉化力か湾つてくる。徒つて成人 1 人 の重夜では適切な標準表が作れないので，6人の成人唾 液に就いて個人差の動摇程度をしらべてみた。
第 4 因成人䑟液裙化力平均標準図

$\left(37^{\circ} \mathrm{C}, 30\right.$ 分 $)$

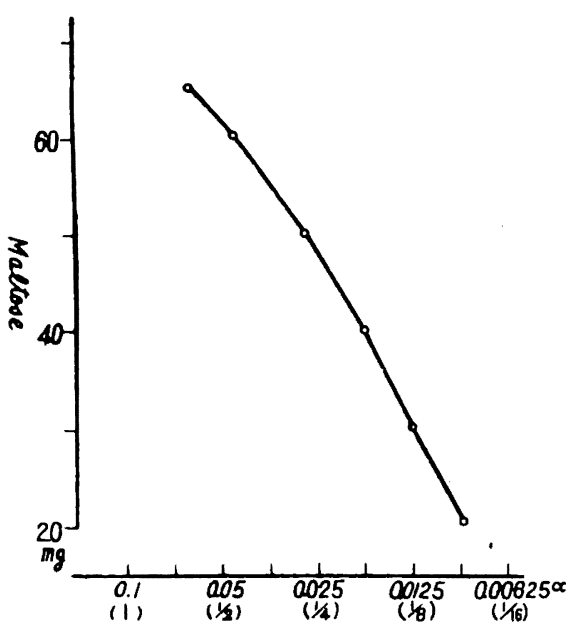

温槽中に浸し, 液の温度上昇を確かめた後, 哽液を作用 させ，(唾旅量に就いては後述する）直ちに硝子棒にて 蚫找し，其後も5 分間隔に㩭找を行い，正確に30分作用 後，N-硫酸 $1 \mathrm{cc}$ を以てアミラーゼ作用を停止した。

第 7 表 成人唾液桾化力の稀釈に上る变動 (力価標集表) $37^{\circ} \mathrm{C}, 30$ 分

\begin{tabular}{|c|c|c|c|c|c|c|c|c|c|}
\hline \multirow{2}{*}{ No. } & \multirow{2}{*}{ 氏 } & \multirow{2}{*}{ 名 } & \multirow{2}{*}{ 性 } & \multirow{2}{*}{ 年令 } & \multicolumn{2}{|r|}{ 唾 } & 液 & \multicolumn{2}{|l|}{ 量 } \\
\hline & & & & & $0.1 \mathrm{cc}(1)$ & $0.05 \operatorname{cc}(1 / 2)$ & $0.025 \mathrm{cc}(1 / 4)$ & $0.0125 \mathrm{cc}(1 / 8)$ & $0.00625 \mathrm{cc}(1 / 16)$ \\
\hline 1 & & $\mathrm{~N}$. & $\hat{\delta}$ & $33 j$ & $79.48 \mathrm{mg}$ & $71.04 \mathrm{mg}$ & $64.96 \mathrm{mg}$ & $52.08 \mathrm{mg}$ & $37.80 \mathrm{mg}$ \\
\hline 2 & & A. & $\hat{o}$ & $31 \mathrm{j}$ & 65.66 & 54.32 & 38.67 & 24.08 & 13.50 \\
\hline 3 & & A. & q & $28 \mathrm{j}$ & 70.84 & 61.57 & 49.56 & 32.62 & 19.85 \\
\hline 4 & & F. & f & $26 \mathrm{j}$ & 71.40 & 64.40 & 50.96 & 33.60 & 20.32 \\
\hline 5 & & $\mathrm{U}$ & 웅 & $18 j$ & 65.80 & 55.30 & 37.83 & 23.63 & 13.22 \\
\hline 6 & & N. & \& & $16 \mathrm{j}$ & 66.22 & 56.70 & 38.10 & 23.63 & 13.22 \\
\hline
\end{tabular}

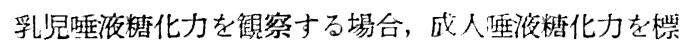
準にしてどの位の力洒であるかしらくこのであるが，藫 者の垁駼は $0.1 \mathrm{cc}$ 哲隻を用いて糖化力を測定しているの で，第 7 表から個人差はあるが大体成人唾液糖化力を $65 \mathrm{mg}$ 以上と見做してよいだ万5と思5。促つて第7表 を参照寸れば測定された乳坚唾夜糖化力は，成人重液の どの位の稀积力洒に相当するかが一見してかかるのであ る。更に第 7 表成績をグラフ上に画き,グラフ上より平 均値を求めて成人唾液糖化力の平均曲線を求め, 力何此 較を簡便ならしめた。（第4困）

\section{第 3 等 験 少 法}

\section{(1) 整洨作用方法}

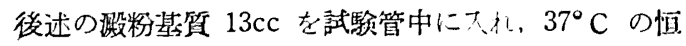

\section{没粉基質—}

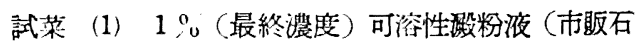
津彆薬可浴性激粉を充分乾燥したもの）

(2) $0.05 \mathrm{~mol}$ (最終濃度) 局方食塩液

(3) Michaelis ${ }^{19)}$ 燐酸緩㣫液 $(\mathrm{pH}=6.7)$

上記洀粉液に食塩液を添加したもの $10 \mathrm{cc}$ に上記綏衝 液 $3 \mathrm{cc}$ を加えたもの，叨ち $13 \mathrm{cc}$ を浿粉基質とした。

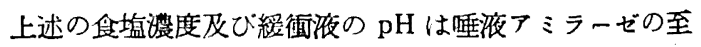
適条件20)にした。

睡液量一

乳児唾液は成人の如く多量に探取する事が難しいの で, 作用唾液量を $0.1 \mathrm{cc}$ こした。0.1cc の唾液量はメス ピヘットを使用して測つたのであるが，使用したメスビ ヘットは次の如き方法で検定した。則ち成人唾夜 $1 \mathrm{cc}$ 
蒸溜水にて10倍に稀釈したものと，使用しょ5とするメ スビへットにて $0.1 \mathrm{cc}$ 取つたものを，上述の如き条件の

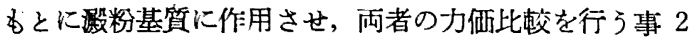
回，その結果同一力価と見做して美支えない範罒の值を 示したメスピヘットを選定し用に供した。

\section{(2) 榶定旦方法}

以上の作用操作を終えた後 Willstätter-Schudel ${ }^{21}$ 法 により，澱粉基質より生ずる糖量を測定した。但し Willstätter-Schudel 法の使用した $0.1 \mathrm{~N}$ 苛性曹達量はN 硫酸を中和し，緩㣫液の酸性矮酸塩を中和し，更にョー

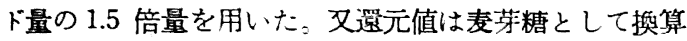
した。（蚛ち $0.1 \mathrm{~N} ヨ$ ヨ゙液 $1 \mathrm{cc}$ は麦芽糖 $17.15 \mathrm{mg}$ に 相当するものとして計算した。

\section{第 4 章 実 験 成 績}

第1節 乳児哂液榶化カの 1 日に於ける消長に就いて 成人唾液消化力の消長倾向に関しては，各人において 一定はしないが，大体朝食前において最も低き傾向があ り，朝食後乃至㡺食後最も高き倾向がある如くいわれて

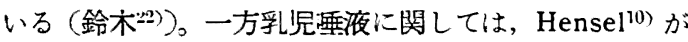
一定の傾向が見られなかつたと報告している。これ等の 成樍はョード反応を利用して測定しているので，著者は 糖化力の面からこの消長傾向に就いて検討してみた。

（1）人工栄養児に於ける，1日の消長に就いて

乳児に於ては食慨（或いは母乳）の摄取時間が定まつ ていない場合が多いのこ，糖化力をしらべても比較をす る際, 個人との場台に於ても或いは成人との場台に於て る消長傾向の適切なる比較がむつかしい。そこで特殊施

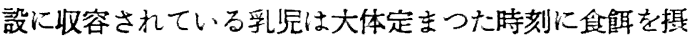
つているので, 著者は石川県立乳巟院に収容されている
比較的発育の良い者 3 名を選び 3 日間に亘り糖化力の消 長に就いて観察した。（第8表）

第 8 表を見るに，1 例汇於ては時間に関係なく消長し ているが，他の 2 例に於ては 14 時頃高い力価倾向を示 すよ5に思われる。又各人に就いて 3 日閒の成績を見る に，1 日の消長倾向は同一人においてはほぼ常に類似の 倾向を示す事かかかる。

次に1日に捄ける力洒の動摇範国に就いて見るなら ば，最高力価と最低力洒の美から大きいものでは 25.63 $\mathrm{mg}$ の開きを示す。この数字は麦芽糖生成量から見た美 であつて、これを一見したたけけでは力価の関係かは吼き りしない。故に第 2 章（3）に示した力価穄準表に照し て，この関係を見ると，この動摇範明は最高力価 77.3 $\mathrm{mg}$ と最低力価 $51.75 \mathrm{mg}$ の開きであるから，最高力価 を 1 とした場合，最低力価は約 8 倍に稀䣋した唾液力価 に相当する事がわかる。促つて動摇筙四は最高力価を 1 之した際, 最低力洒は約 $1 / 8$ であり，逆に最低力価を 1 とすれば最高力価は約 8 倍の糖化力であるといえる。こ の事を $1 \sim 1 / 8$ 動摇範四と記すことにする。(以下この 样式に徒つて記す)

そこで第 8 表の成樍から動摇範囲は大きい場合は 1 $1 / 8$ 位の範围であるが大低は $1 \sim 1 / 2$ 以内の間を動摇す る事がわかる。即ち大体 1 日の動摇範囲は最高力価を 1 とすれば最低力価は約 $1 / 2$ である。

(2) 母乳栄養児に於ける1日の消長に就いて

母乳栄㾞の際はそれぞれ異つた時間に母乳が与えられ ているのではつきりした消長倾向は見られないだろら か，母乳栄養览 6 名に就いて起床後母乳を摂らない内に 第 1 回喠液抔取を行い ( 8 時頃)，以後如何なる力伍消 長を示すか観察し第 9 表の成績を得た。

第 8 表人工栄独児の 1 日に於ける榶化力の消長 ( 3 日間)

\begin{tabular}{|c|c|c|c|c|c|c|c|c|c|}
\hline & & & & & $\downarrow 5$ 時 & $\begin{array}{c}\text { 飭 } \\
\downarrow \\
\downarrow\end{array}$ & $\begin{array}{l}\text { 投 与 } \\
\downarrow 12 \text { 時 }\end{array}$ & $\begin{array}{l}\text { 時 } \\
\downarrow 15 \text { 時 } \\
\end{array}$ & \\
\hline 氏 名 & 重 & 性 & 月合 & 栄 淟 方 法 & 時 & 11 時 & 14 時 & 17 時 & 消長範囲 \\
\hline H.U. & $9 \mathrm{~kg}$ & $\hat{\jmath}$ & $8 \mathrm{M}$ & $\begin{array}{l}4 \text { 力月前加ら重湯添加 } \\
\text { 現在 } 5 \% \text { 重湯十粉乳+ } \\
(2 \text { 力月前加ら) } 3 \text { 分栊 }\end{array}$ & $\begin{array}{c}67.71 \mathrm{mg} \\
51.75 \\
69.19\end{array}$ & $\begin{array}{c}74.48 \mathrm{mg} \\
66.75 \\
70.86\end{array}$ & $\begin{array}{c}69.17 \mathrm{mg} \\
77.38 \\
79.71\end{array}$ & $\begin{array}{c}71.57 \mathrm{mg} \\
64.80 \\
79.71\end{array}$ & $\begin{array}{c}6.77 \mathrm{mg} \\
(1 \sim 1 / 2) \\
25.63 \\
(1 \sim 1 / 8) \\
10.52 \\
(1 \sim 1 / 3)\end{array}$ \\
\hline S.H. & $8.17 \mathrm{~kg}$ & $\delta$ & $5 \mathrm{M}$ & $\begin{array}{l}2.5 \text { 力月前から重湯添加 } \\
\text { 現在 } 5 \% \text { 重湯十粉乳 }\end{array}$ & $\begin{array}{l}40.64 \\
41.12 \\
53.69\end{array}$ & $\begin{array}{l}42.55 \\
43.24 \\
47.88\end{array}$ & $\begin{array}{l}51.75 \\
58.04 \\
63.52\end{array}$ & $\begin{array}{l}41.60 \\
52.23 \\
56.85\end{array}$ & $\begin{array}{c}11.11 \\
(1 \sim 1 / 2) \\
16.92 \\
(1 \sim 1 / 2) \\
9.83 \\
(1 \sim 1 / 2)\end{array}$ \\
\hline J.K. & $6.71 \mathrm{~kg}$ & f & $5 \mathrm{M}$ & $\begin{array}{l}2 \text { 力月前加ら重湯添加 } \\
\text { 現在 } 3 \% \text { 重湯+牛乳 }\end{array}$ & $\begin{array}{l}33.87 \\
33.87 \\
37.25\end{array}$ & $\begin{array}{l}24.68 \\
32.88 \\
36.93\end{array}$ & $\begin{array}{l}24.20 \\
31.92 \\
35.65\end{array}$ & $\begin{array}{l}18.87 \\
34.83 \\
37.32\end{array}$ & $\begin{array}{c}15.00 \\
(1 \sim 1 / 2) \\
2.91 \\
(0) \\
1.67 \\
(0) \\
\end{array}$ \\
\hline
\end{tabular}


第 9 表 母乳栄落児の 1 日に於ける桾化力の消長

\begin{tabular}{|c|c|c|c|c|c|c|c|c|c|c|}
\hline No. & 氏 名 & 性 & 令 & 体 重 & $\begin{array}{c}\text { (起床時) } \\
8 \text { 時 }\end{array}$ & 11 時 & 14 時 & 時 & 長 & 䇛 \\
\hline 1 & E.N. & क & $3 \mathrm{M}$ & $6.59 \mathrm{~kg}$ & $40.78 \mathrm{mg}$ & $38.41 \mathrm{mg}$ & $48.89 \mathrm{mg}$ & $50.15 \mathrm{mg}$ & $10.48 \mathrm{mg}$ & $(1 \sim 1 / 2)$ \\
\hline 2 & S.M. & 우 & $3 \mathrm{M}$ & 5.58 & 41.02 & 50.23 & 52.53 & 53.33 & 11.51 & $(1 \sim 1 / 2)$ \\
\hline 3 & H.T. & $\hat{ث}$ & $3 \mathrm{M} 14 \mathrm{~T}$ & 6.75 & 45.57 & 45.57 & 60.75 & 56.15 & 5.17 & $(1 \sim 1 / 2)$ \\
\hline 4 & M.N. & 우 & $6 \mathrm{M}$ & 8.20 & 52.76 & 61.90 & 60.94 & 60.46 & 9.14 & $(1 \sim 1 / 2)$ \\
\hline 5 & T.K. & ㅇ & $8 \mathrm{M}$ & 7.50 & 32.85 & 54.90 & 40.53 & 34.30 & 22.05 & $(1 \sim 1 / 3)$ \\
\hline 6 & MIS. & $\delta$ & $12 \mathrm{M}$ & 8.25 & 39.03 & 55.60 & 47.95 & 48.13 & 16.57 & $(1 \sim 1 / 2)$ \\
\hline
\end{tabular}

母乳栄養少の 1 日の消長を見るに, 早朝空腹持におい ては大体最も低い力唒向があるよ5に思う。そして以 後の消長は各人により一定はしていないか，11時～14時 頃を最高の打価とした消長倾向を示すよにに考えられ る:

次:1日の力洒の動摇範国を見る: 第 9 表から大体 1ー1２位の間を動搡寸るものと思5。即ち正午頃の最

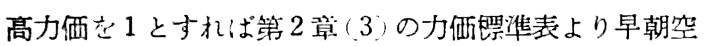
腹時の最低力洒は 2 倍稀 の約 $1 / 2$ の力洒を示寸事にな る。

(3)成人重液棈化力の 1 日に於けっる消長との比較 乳児の消長值向と比較する為, 成人 3 名:就いて 1 日 の消長を観察した。(第10表)
思われる。勿論著者の如き測定時閒では飭事の影響がは つきり現れ難いのであるか，朝食前の力洒から見て明ら かに食事の影殆ある事が感じられる。然し1日の消長は 食事の前後の力価変動ばかりでなく14時頃を最高力価と して再ひ次第に力価が下つて行くよ５な倾向が見られ る:このような傾向は各人によつて一定ではないたろう か，乳児の場合に於いても，朝食前に相当する時間にお いて最低力価を示し, 以後の消長は成人の如く明らかで はないが，大体11時～14時項が最高となる倾向があるよ うに思われる。

又1日の動括範困は著しい動摇を示す者もあるが大体 成人と同じょうに1〜1/2 以内において消長している。

第 2 節 乳児及び成人喂液榶化カの日による变動比较

第 10 表成人唾液榶化力の 1 日に於ける消長

\begin{tabular}{|c|c|c|c|c|c|c|c|c|c|c|c|c|c|}
\hline \multirow[b]{2}{*}{ No. } & \multirow[b]{2}{*}{ 氏 } & \multirow[b]{2}{*}{ 年令 } & \multirow[b]{2}{*}{7} & \multicolumn{2}{|c|}{$\begin{array}{c}\text { 朝食 } 8 \text { 時 } \\
\downarrow\end{array}$} & \multicolumn{3}{|c|}{$\begin{array}{c}\text { 疍食12時30分 } \\
\downarrow\end{array}$} & \multicolumn{4}{|c|}{$\begin{array}{c}\text { 夕食18時 } \\
\downarrow\end{array}$} & \multirow{2}{*}{ 消長範囲 } \\
\hline & & & & 時 & 10 & 時 & 14 & 時 & 17 & 時 & 19 & 時 & \\
\hline 1 & S.A. & $6 j$ & & $\mathrm{mg}_{51.12}^{\mathrm{mg}}$ & & $\begin{array}{c}\mathrm{mg} \\
60.83\end{array}$ & & ${ }_{63.65}^{\mathrm{mg}}$ & & $\underset{54.48}{\mathrm{mg}}$ & & ${ }_{54.23}^{\mathrm{mg}}$ & $1 \sim 1 / 2$ \\
\hline 3 & K.F. & $26 \mathrm{j}$ & & 60.45 & & 67.00 & & 78.53 & & 66.14 & & 69.16 & $1 \sim 1 / 6$ \\
\hline 3 & T.A. & $31 \mathrm{j}$ & & 51.35 & & 58.05 & & 62.52 & & 63.83 & & 56.02 & $1 \sim 1 / 2$ \\
\hline
\end{tabular}

位来成人唾液消化力に就いては, 食事の前後をしらぺ ると食後に著しく消化力か上昇寸る事は認められており

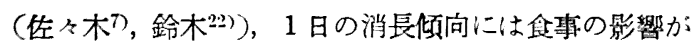
当然考えられる。そこで第10表を見るに，僅か3例であ るので明らかな推測は許されないが，各例共朝食前に於 いて最も低い力洒を示し，14時頃最高力価を示すよ5に
第 8 表の成絈から同一人においては 1 日の消長傾向は 大略常に類似の傾向あるよ5に思われるので, 次に日に よつてどれ程の変動があるものか, 乳児と成人とに就い て14時頃の探取吽液の栯化力をしらべ比較してみた。乳 児に就いては第 8 表の成績を引用した。（第12表）

第 11 表 成人唾液晤化力の日による変動に就いて

\begin{tabular}{|c|c|c|c|c|c|c|c|c|}
\hline No. & 氏 名 & 年 令 & 日/月 & $18 / 9$ & $30 / 9$ & $5 / 10$ & 変 動 & 範 囲 \\
\hline 1 & Y.N. & $33 j$ & & $75.53 \mathrm{mg}$ & $78.32 \mathrm{mg}$ & $78.48 \mathrm{mg}$ & $2.95 \mathrm{mg}$ & g (0) \\
\hline 2 & T.A. & $31 j$ & & 68.55 & 64.52 & 72.55 & 8.03 & $(1 \sim 1 / 2)$ \\
\hline 3 & K.F. & $26 \mathrm{j}$ & & 69.32 & 66.45 & 68.22 & 2.87 & . $(0)$ \\
\hline 4 & E.U. & $18 \mathrm{j}$ & & $63 \cdot 28$ & 56.28 & 67.00 & 10.72 & $(1 \sim 1 / 2)$ \\
\hline 5 & S.A. & $6 \mathrm{j}$ & & 65.05 & 65.22 & 58.23 & 7.29 & $(1 \sim 1 / 2)$ \\
\hline
\end{tabular}


第 12 表 乳児唾液糟化力の日による变動に就いて

\begin{tabular}{|c|c|c|c|c|c|c|c|}
\hline No. & 名 & 月 令 & 日/月 & $18 / 11$ & $20 / 11$ & $22 / 11$ & 変 動 範 国 \\
\hline 1 & H.U. & $8 \mathrm{M}$ & & $69.17^{\mathrm{mg}}$ & $77.38^{\mathrm{mg}}$ & $79.71^{\mathrm{mg}}$ & $10.54^{\mathrm{mg}}(1 \sim 1 / 3)$ \\
\hline 2 & S.H. & $5 \mathrm{M}$ & & 51.75 & 58.04 & 63.52 & $(I \sim 1 / 2)$ \\
\hline 3 & J.K. & $5 \mathrm{M}$ & & 24.20 & 31.92 & 35.65 & $(1 \sim 1 / 2)$ \\
\hline
\end{tabular}

著者の用いた糖化力表示は, 第 2 章 (1) に述べた如く 力価の高いものでは糖化曲楾屈曲後測定されるので, 变 動範囲は小さく表われてくるのは当然である。しかし表 （第11，12表）を見てわかるよ5に大きい動摇を示す者 でも，1１/3以内放いて变動しており，大低は $1 \sim 1 / 2$ の範囲内に変動している。即ち力価の高く表れる場合を 1 とすれば, 低い場合はその 1/3～1/2 力価を示すこと がわかる。

\section{苐3 節 月令别に見た乳児唾液榶化カに就いて}

乳児棰液粕化力が月令の進さにつれて如何なる上昇を 示すものか，月令別に観察すると同時に一方個人に就い

て追求してみた。

(1) 乳览哑液榶化力の月令別観察

著者は 1 力月～ 12 力月に亘る健康乳巟74名に就いて月 令別にしらべ，第13表の成緝を得た。（唾液探取は14時 〜15時の間に行つた)

第 13 表乳児唾液榶化力の月令別観察成績

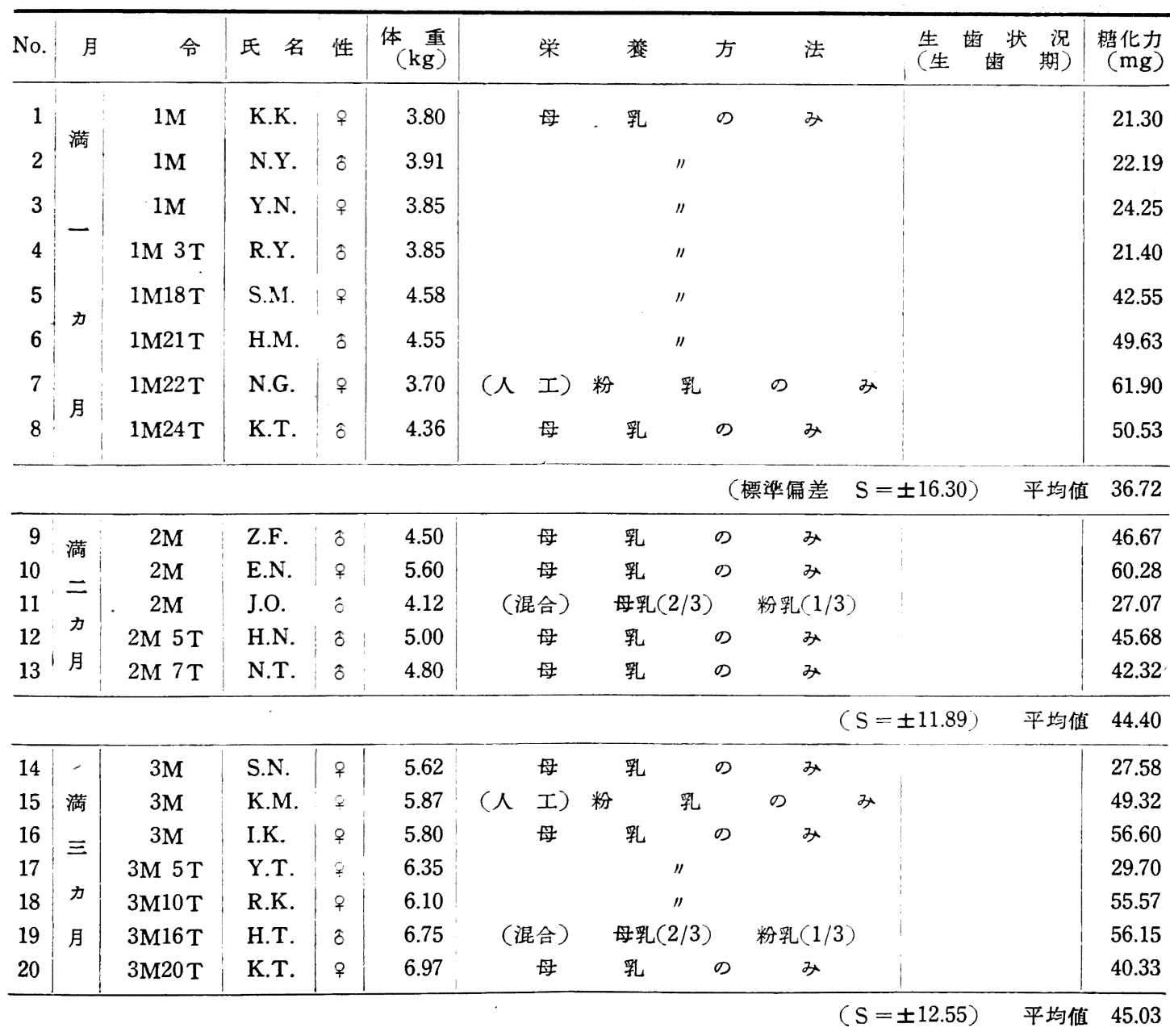


栄滛と、食䊓

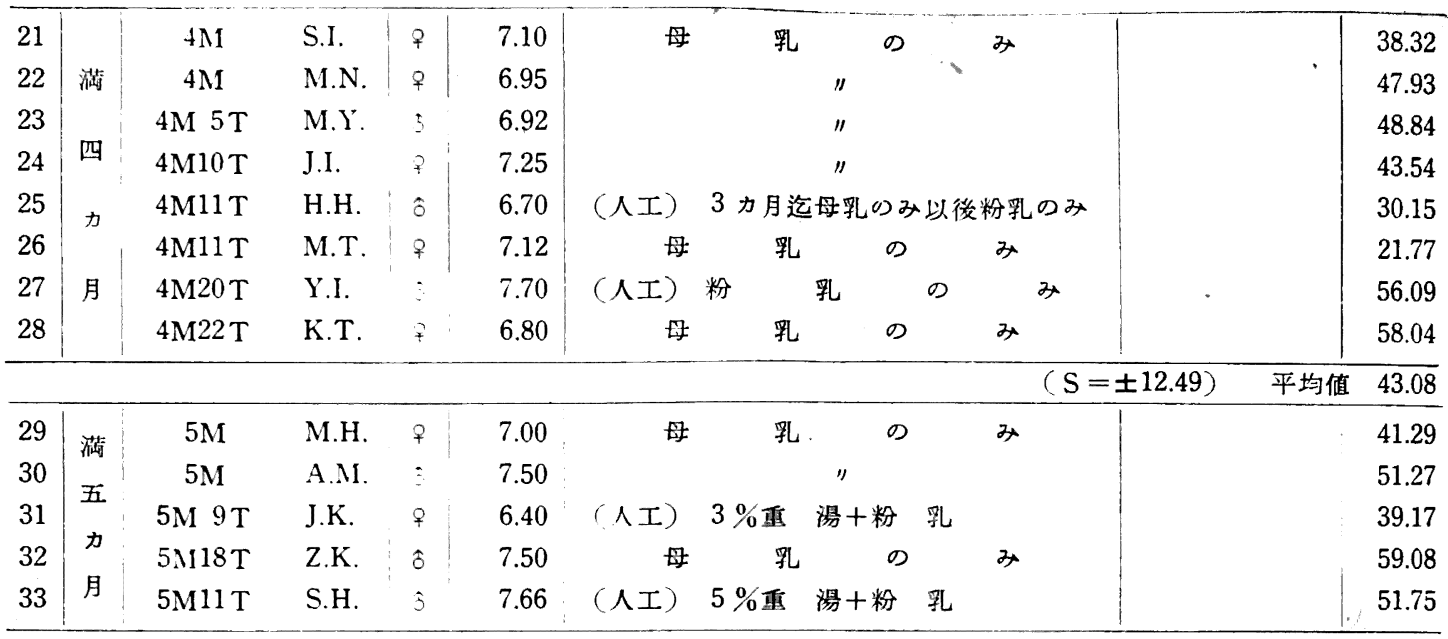

\begin{tabular}{|c|c|c|c|c|c|c|c|c|c|}
\hline \multirow{2}{*}{ 満 } & $6 \mathrm{M}$ & A.M. & 우 & 7.12 & 母 & 乳 & の & \multirow{6}{*}{$\frac{00100}{0010}$ ( 5 カ月) } & 44.65 \\
\hline & $6 \mathrm{M}$ & M.M. & 3 & 5.62 & （混合） & 母乳(2/3) & 粉乳 $(1 / 3)$ & & 70.61 \\
\hline 六 & $6 \mathrm{M} 6 \mathrm{~T}$ & Y.I. & ㅇ & 7.88 & & 母乳(4/5) & 梠(10日前以来) & & 61.48 \\
\hline 力 & $6 \mathrm{M} 13 \mathrm{~T}$ & K.M. & $\hat{o}$ & 8.80 & (人工) & 款粉及び粉 & 乨( 4 カ月頃上り) & & 65.28 \\
\hline \multirow{2}{*}{ 月 } & $6 \mathrm{M} 20 \mathrm{~T}$ & K.M. & $?$ & 7.00 & 母 & 乳 & み & & 47.38 \\
\hline & $6 \mathrm{M} 22 \mathrm{~T}$ & J.F. & o & 7.50 & （混合） & 母乳( $(2 / 3)$ & 重湯 ( 1 週間前上り) & & 58.04 \\
\hline
\end{tabular}

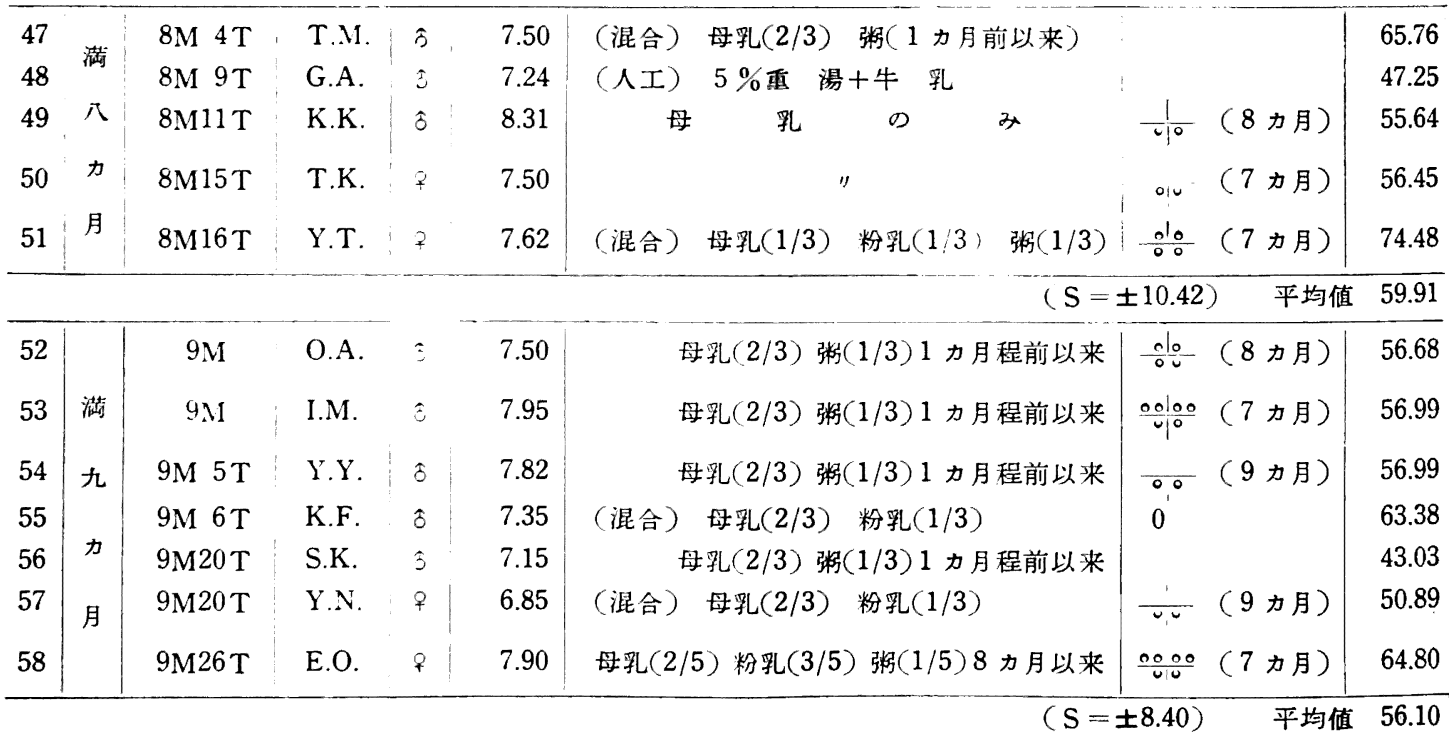


第 7 巻 第 5 号

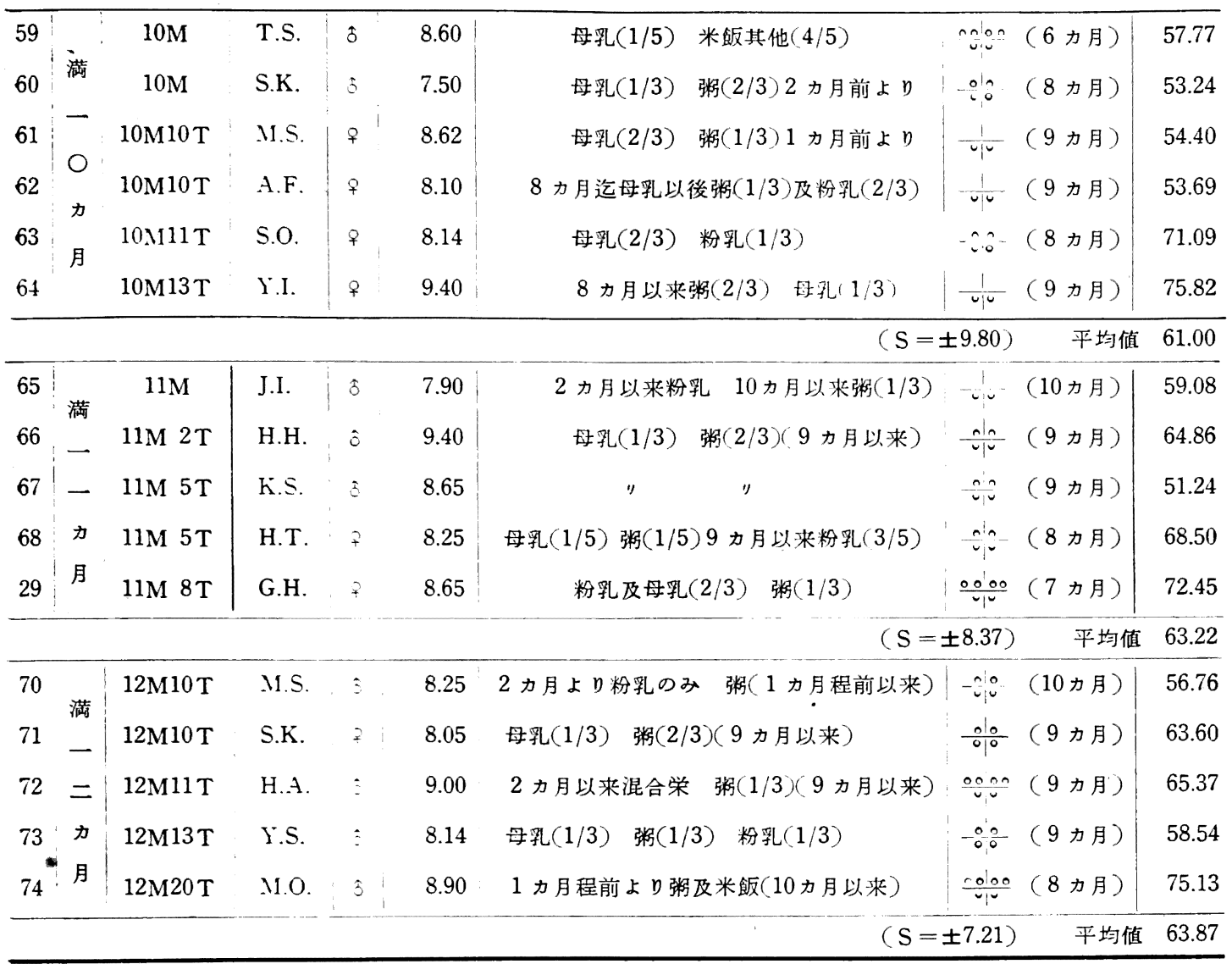

第13表の成繥を見て明らかな如く, 整液糖化力には相 当個人差があり，又体重及び性別に無関係である事がわ かる。

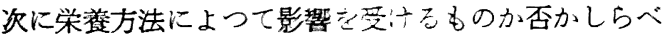
るため表中より人工栄趇の場台のみを抽出したのが第14 表である。

第 14 表人工栄澺児の唾液旗化力

\begin{tabular}{|c|c|c|c|c|c|c|c|}
\hline No. & 氏 名 & 令 & 栄 & 意 方 & 法 & $\begin{array}{l}\text { 醥化力 } \\
\text { (mg) }\end{array}$ & $\begin{array}{l}\text { 月令平均 } \\
\text { 值 (mg) }\end{array}$ \\
\hline 1 & E.I. & $21 \mathrm{~T}$ & 粉 & & 我 & 60.46 & \\
\hline 2 & N.G. & $1 \mathrm{M} 22 \mathrm{~T}$ & & $"$ & & 61.90 & $\begin{array}{c}(1 \mathrm{M}) \\
36.72\end{array}$ \\
\hline 3 & K.M. & $3 \mathrm{M}$ & & $"$ & & 49.32 & $\begin{array}{c}(3 \mathrm{M}) \\
45.03\end{array}$ \\
\hline 4 & S.I. & $4 \mathrm{M} 20 \mathrm{M}$ & & " & & 56.09 & $\begin{array}{c}(4 \mathrm{M}) \\
34.08\end{array}$ \\
\hline 5 & J.K. & $5 \mathrm{M} 9 \mathrm{~T}$ & $3 \%$ & 重湯 + & 物乳 & 39.17 & $\begin{array}{c}(5 \mathrm{M}) \\
48.51\end{array}$ \\
\hline 6 & S.H. & $5 \mathrm{M} 11 \mathrm{~T}$ & $5 \%$ & 重湯+ & 粉乳 & 51.75 & \\
\hline 7 & H.U. & $7 \mathrm{M} 24 \mathrm{~T}$ & $5 \%$ & 重湯+ & 物乳 & 68.67 & $\begin{array}{c}(7 \mathrm{M}) \\
59.62\end{array}$ \\
\hline 8 & G.A. & $8 \mathrm{M} 9 \mathrm{~T}$ & $5 \%$ & 重湯 + & 粉乳 & 47.25 & $\begin{array}{c}(8 \mathrm{M}) \\
59.91\end{array}$ \\
\hline
\end{tabular}

人工栄掌の場合においてみるに，No.1 及びNo.2の

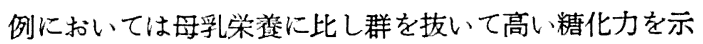
し, No. 3 及び No. 4 に执いても月令平均值よりも幾分 高い力洒が見られるので，月令の若い時期に拈いては母 乳栄洤に比し, 人工栄䔲の場合糖化力はやや高い倾向が あるよ5に思5。

又, 徒来澱粉添加によつて唾液消化力が順応して上年 寸るかど5かの問題に関し, Finizio9) の順応説と, 早産 児に就いて央験したHensel ${ }^{10}$ :の非順心説があるが,この 点に就いては著者は特別な垁験を行わなかつたのではつ きりした結論はいい得ないが，第13，14表を通じて澱粉 添加栄盖児か非濒粉添加栄荃児に比し, 或程度高い糖化 力を示す樣であるが，余りはつきりした差異ではない。

以上栄養方法と糖化力の関係に就いて見たのである か，次に䌅化力が月令の進むにつれて如何なる上昇を示 すか観察してみよ5。

そこで糖化力上昇傾向をわかり易くする為第13表成緛 をグラフ上に点で表わして見ると第 5 図の如くなる。

第 5 図を見るに, 各月令の平均值は月令の進むにつれ て上昇し 6 力月垻迄は急激なる上帠を示すよ5に思う。 
又以後の上昇は幾分緩やかとなるが12 月月頃迄糖化力增 加が認められる。

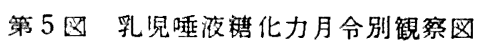

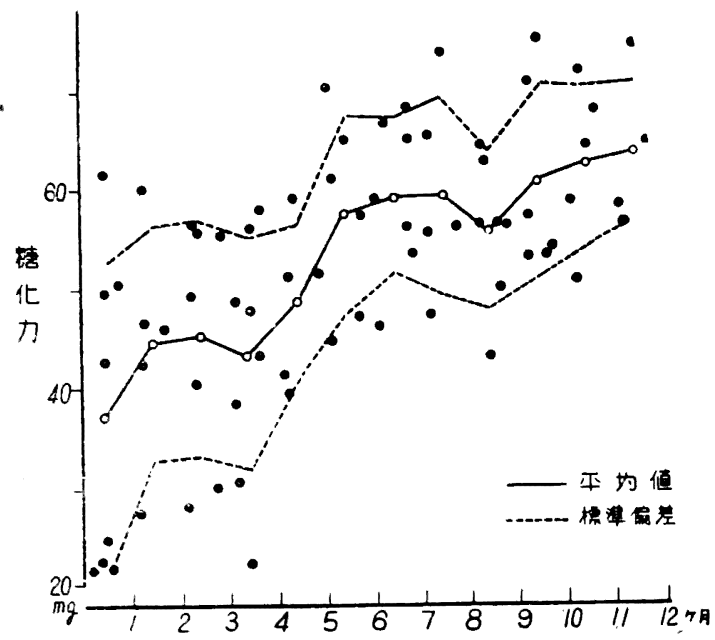

一方個人差に溨いて月令別に唒準偏差を求めてしらべ ると，5 力月頁迄は撒布度が公い倾向か暴わ机る。そこ て 6 力月以前とてカ月以後の二群に分けて分散を求めて みると次表の如くなる。

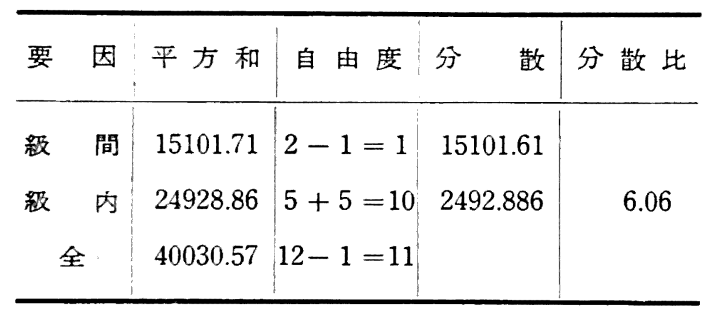

佂つて $5 \%$ の危険率で級間に差があるといえる。即ち 両者の間に差が茨められ， 7 カ月以後には撒布度が小さ くなつている事がわかる。勿論著者の糖化力湘定法は力 価の高い者では糖化曲線屈曲後測定されるので，成人唾 液力価に近づくにつれて祭準偏差は小さくなつて行くの であるが，撒布度が小さくなつて行く傾向のある事は， 低い力価のものが次第に上昇して行く事を意味するので ある。

双て月令の進むに順じ糖化力が上昇して行く事は疑な。

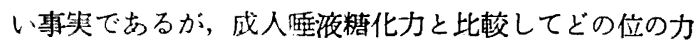
洒を有するるのか, 又如何程の力価上舁を示して行くも のかに就いて観察してみよ5。

第 2 章 (3) に述へたた力価骠隼表及び区を参照して乳児 哽液榶化力を見るならば，1 カ月乳览に於ては既に高い 方では成人の $1 / 3$ 位の力価を有する者むあり, 一方低い 方では $1 / 10 \sim 1 / 12$ 位の力価を示す。促つて平均値から 見る場合は成人の約 1/6 1/8 の糖化力を有する事にな る。そして月令の進むにつれ次第に上乐し 6 力月頃に至 れば, 平均值は成人の約 $1 / 2 \sim 1 / 3$ 力伍になつて来る。

か梯に乳少唾液糖化力は 6 力月頃迄急激な上昇を見る が，以後の上舁は綏やかで，平均値から見る時，一般的 には 9 〜 10力月頃から成人力価に近似するよ5である。

（2）乳览唾液榶化力の個人別追求成績

糖化力の月命につれて上昇する事はわかつたが, 個人 別に追求した場合, 如何なる上犁倾向を示するのか, 健 康乳贤10名に就いて 1 力月毎に 3 力月に亘つて追求し, 第15表の成綪を得，この表から上昇度を見易くする為第 6 図を作つた。

第 15 表乳児唾液槽化力の 3 力月追求成䋶

\begin{tabular}{|c|c|c|c|c|c|c|c|c|c|c|}
\hline $\begin{array}{l}\text { No. } \\
\text { 氏 名 } \\
\text { 月 令 }\end{array}$ & $\begin{array}{c}1 \\
\text { N.Y. } \\
1 \mathrm{M}\end{array}$ & $\begin{array}{c}2 \\
\text { S.M. } \\
1 \mathrm{M} 18 \mathrm{~T}\end{array}$ & $\begin{array}{c}3 \\
\text { H.M. } \\
\text { 1M21 T }\end{array}$ & $\begin{array}{c}4 \\
\text { Z.F. } \\
2 \mathrm{M}\end{array}$ & $\begin{array}{c}5 \\
\text { K.T. } \\
3 \mathrm{M} 20 \mathrm{~T}\end{array}$ & $\begin{array}{c}6 \\
\text { S.I. } \\
4 \mathrm{M}\end{array}$ & $\begin{array}{c}7 \\
\text { K.M. } \\
6 \mathrm{M} 20 \mathrm{~T}\end{array}$ & $\begin{array}{c}8 \\
\text { N.M. } \\
\text { 7M 3T }\end{array}$ & $\begin{array}{c}9 \\
\text { I.M. } \\
9 \mathrm{M}\end{array}$ & $\begin{array}{c}10 \\
\text { Y.Y. } \\
9 \mathrm{M} 5 \mathrm{~T}\end{array}$ \\
\hline 1 力月 & $\begin{array}{c}\mathrm{mg} \\
22.19\end{array}$ & 42.54 & 49.63 & & & & & & & \\
\hline 2 力月 & 28.54 & 45.25 & 42.86 & 46.67 & & & & & & \\
\hline 3 力月 & 48.04 & 43.01 & 57.53 & 38.58 & 40.33 & & & & & \\
\hline 4 力月 & & & & 50.34 & 34.26 & 38.32 & & & & \\
\hline 5 力月 & & & & & 43.43 & 40.47 & & & & \\
\hline 6 力月 & & & & & & 57.53 & 47.38 & & & \\
\hline 7 カ月 & & . & & & & & 48.22 & 53.86 & & \\
\hline 8 力月 & & & & & & & 59.76 & 48.12 & & \\
\hline 9 力月 & & & & & . & & & 55.43 & 56.99 & 56.99 \\
\hline 10 力月 & & & & & & & & & 59.16 & 61.91 \\
\hline 11 力月 & & & & & & & & & 61.80 & 62.75 \\
\hline 12 力月 & . & & & & & & & & & \\
\hline
\end{tabular}


第 6 因孚览唾被化力の 3 力月追求成續

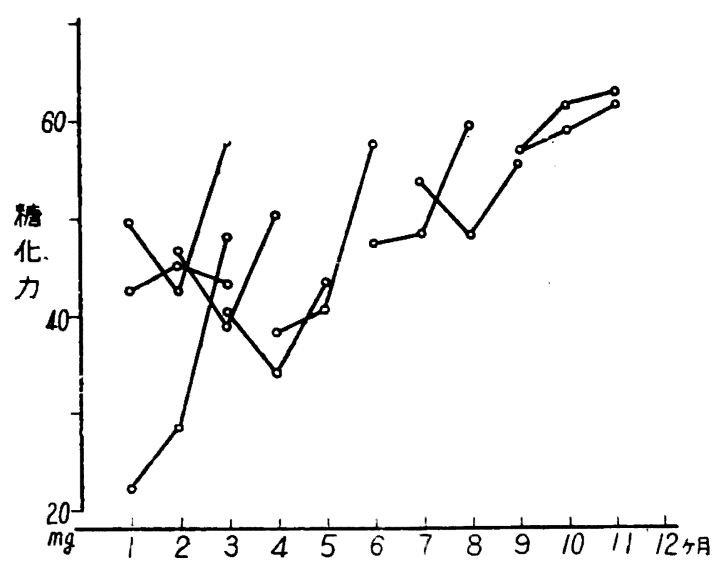

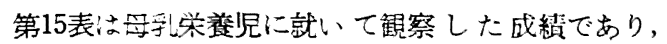
No. 9 及ざ10の例は弱食を摃取している。従つて他の 8 例では澱粉食の添加が無いが，凡ての例に於いて上昇倾 向が見られ，特に6カ月以前において顕著である。この 成精からも明らかな如く激粉添去の有無に拘らず糖化力 は上昇を示す事が認められる。

\section{第 5 章 総括並びに考察}

乳児液の澱粉消化力に就ては, Korowin ${ }^{3)}$, Schlos$\operatorname{sman}^{4}$ 等によつて生後第 1 日目から消化力を有する事 は認められているが, 液の分泌量も3 3 月頃迄は非常 に少ないるのと思われているので, 乳问の人工栄莒の際 は一般に消極的な態度をとられているのか現況である。 そこで著者の奏駼成綪を見るに, 生後 1 力月乳児の糖化 力は低い方では成人重液榶化力の約 1/10１/12 の力価 を示すか，高い方では既に成人の $1 / 3$ 位の糖化力を有す る事がかった。

又乳児院収容の生後21日の人工栄荃览一例に就いてし らべた糖化力では, 意外に高い力価を示し既に成人の約 1/2 の力洒を有する事が判明した。然しこのよ5な力洒 は特別な例であるのでこの力牺から乳览軼液の力洒を推 測出来ない，一般には 1 力月以内においては, 恐らく成 人の約 1/10１/12 前後の力価を有するものであろ 思われる。勿論著者の㬰駼成績は锃液分泌量を测定して いないのて，潕液量の多い場台と少ない場合とでは糖化 力に当然影響してくる事が考えられ，測定された力洒は 正確な糖化能力といい難いし, 又媓液アミラーゼ作用は 胃の酸によつて非働化されるので，唾液糖化力を以つて 澱粉消化の問題を論ずる事は許されないか，消化器系統 の機能力を推測する一指針として重液糖化力を見る場合

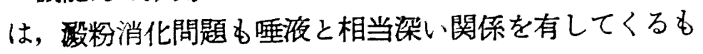
のと考えられる。この観点に立つて上記の倕液糖化力観

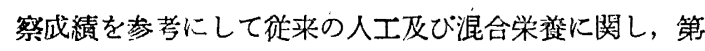
2 含水炭素添加の時期及び濃度に就いて見るに，非労に 早期から与える事を酠める人と，遢れて慎重に与える人 とがあるか，本邦に於ては人工栄整の際一般に生後 3 週 閴より $0.5 \%$ の重晹を源加し始め， 2 力月以後 $1 \sim 2$ \%に上昇して与えている現沇である。然し一方には生後 2 週間迄 $2 \%, 1$ 力月以後 $3 \%, 2$ 力月以後 $4 \%$ と非常 に積煰的な意見を提唱している者もある。

この第 2 合水炭素の添加は体重の增加等からみて育児 栄篮学的に重大な意義を有し，早期から惯度を高くして 与える事が理想であるか，上述の如く乳児唾液消化力を 過小に見る倾向が強いため消凿的な栄萑方法が用いられ ているよ5に思われる。

勿論乳少の埏の性状等に就いて細心の注意は怠る事が 出来ないか，少量から始め次第に邪らして行くならば, 著者の成績から見て程極的な栄整方法も必ずしも無理で はないと考える。

従来 Simchen"23) の矢駼が乳児の人工栄盖の参考によ くされるのであるが，彼の垁駼によると乳巟に溜粉を与 えた際, 蕉便に出るョード反応陽性率は生後 $1 \sim 2$ カ月 は70\%，4 カ月頃になると50\%に減少し 8〜9 カ月頃が $0 \%$ と報告している。㹱つて第 2 含水炭素の款粉等は 5 〜 6 カ月頃から与えている場合が多いか，著者の垁験を 見るに既に 2 力月頃の平均糖化力は成人唾液糖化力の約 1/4 に上界してくるので，重湯の濃度はい5に及ばず， 恽粉の添加時期に就いても可成り䅡極的な栄養方法を行 い得るものと考える。

次に上昇倾向に就いてみるに，従来搌粉添加によつて 消化力か順応して上昇して行くものかどうかの問題に関 し, Finizio9 は普通の母乳栄堤の際は上昇がなく澱粉 添加によつて 7 カ月以上の乳児に上昇を認め 3 カ月以下 の乳児においては認めなかつたと報告している。

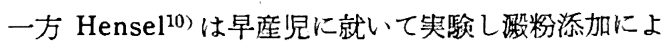
る順応上笔を認めなかつた事を発表している。藷者は澱 粉添加による特別な些験は行わなかつたので，はつきり した事はいえぬが或程度の順応性は認められるが，必ず しも澱粉を与える事により急激に上昇寸るよ5な倾向は 見られないとしてょい成績を得た。

又汼粉添加をしなくても, 月令別観察成績から普通の 母乳栄雀児においても上昇が見られ，更に 3 力月追求成 績によつて子明らかに母乳栄養児においても糖化力上舁 を確認出来たので，Finizio9の説に対しては肯け得ない ものがある。

上昇度に就いては糖化力平均值からみる埸台, 1 力月 乳児において成人唾液糖化力の約 $1 / 6 \sim 1 / 8$ 力価を示す が月令に順じ次第に上昇し，6 カ月頃に至れば約 1/2 
13 の力価となり，9－10力月頃から成人唾液とほぼ一 致してくる如く思われる。

そこで上昇倾向に就いて，彷来の糊精化作用上より観 察された業綪と比較するに，月令別上舁度に就いてはこ れ迄の研究は観察例数が少なく, 月命別に細かく上杽度 を観ていないので比較が困難であるが，成人唾液消化力 に近似する時期に就いて Nicory ${ }^{5}$ ( は満 1 年頃一致する ものであろうといい，他の研究者も六体 Nicory と同じ よ5な見解を下している。本邦に於ては俣野》，佐々末9) が9 カ月頃から近似しているものであ万５といてい

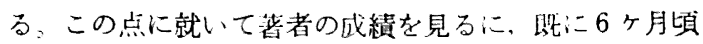
から成人と同等の力価を有寸る者が可成り現九，かつ力 価の低い者は非常に少くなる。しかし平均值から見ると 9１0カ月頁に大体成人の值になるよ5であるので，征 来糊精化作用上より 9 ～12 力月頃といわれているのとほ ぼ等しい成績といえる。

中鉢”‘は人工栄竞の際, 生後約半年は身長の発育はほ ぼ普通に近いが体重增加は普通より少い場合が多い。然 し $5 \sim 6$ 力月頃以後, 乳以外の食物毁ち附加食を与之始 めると全発育が良好になつてくるといつている。この事 は上述した榶化力作用からも理解され得る事であつて， 既に 6 力月頃から成人の力価に近ついてくるのであるか ら,この頃から乳栄荃より次第に離れ得るものであろ 5 。

一方母乳栄荃の場台において, 6 力月頃から離乳準備 汸かる事が臨められているのも上述の糖化力状況から 妥当であるといえる。

以上乳児の人工策盖に就いて，著者の矢験成績から私 見を加えたのであるが，次に乳巟唾㾞の 1 日の消長に就 いて附言する。即ち Finizio9”報告によれば乳児㕵液 消化力は正午に最高の力洒を示すといつているか，Hen$\mathrm{sel}^{10)}$ は早座児に就いて夷験し, 一定の倾向を認めなか つたと報告している。二の点に就いて著者の成績を見る ならば，1日の消長傾向は各人にょつて一定はしない が，同一人にあつては活渂に類似の倾向があり, 又早 朝空腹時においては最も低く正午頃高い力洒倾问がある ように思われる。

\section{第 6 章 絬論}

健康乳昌の獣液糖化力に就いて観察し次の如き結論を 得た。

(1) 糖化力の強弱は性別及び体重に無関係である。

(2) 1 日の消長傾向は，各人により一定しないが，同 一人にありてはほぼ常に類似の倾向があるょうに思わ 放，又早朝空腹時に最も低く正午頃最も高い㑔向がある ようである。
（3）糖化力は澱粉添加の有無に拘らず，月令の進むに つれて上昇する。即ち生後 1 力月乳児の糖化力平均值は 成人糖化力の約 1/6-1/8 の力洒を示すが，6 力月頃に 至れば平均値は約 $1 / 2 \sim 1 / 3$ となり月令に順じ上舁して 行く事が肯かれる。一方個人の追求成絽からも同憡な上 舁倾向が双ら机た。

（4）成人唾液糖化力に近似する時期に就いては, 既に 6 力月頃から相当近つき, 平均的に見て 9 - 10力月頃か らほぼ成人に近い力侸を示すよ5になると考えられる。

稿を終るに臨み, 終始御郎篤なる御指導並びに御校閲 を晹つた諰師石崎教授に浾腹の謝意を表すると共に, 種 々助言を戴いた三根助教授及び荒木学兄に哚甚の謝意を 表す。

\section{参考文 献}

1) Ibrahim: D. H. u. A. H., Zs. f. Kindheilk. Bd. 35, 10 (1923) 引用

2) Moll, L. : Monatschrift Kindheilk. 4,307(1905)

3) Korovin, J. : Jb. Kindheilk. 8,381 (1875)

4) Schlossman, A.: Jb. Kindheilk. 47, 116 (1898).

5) Nicory,Cl. : Biochem. J. vol. 16, No. 3, 387 (1922)

6) D.H.u.A.H. : Zs. f. Kindheilk. Bd. 35, 10 (1923)

7) 佐々木流道: 日本消化器病学雑誌 26 巻 (1927)

8）俣野景吉：台湾医学会雑誌99号～110号 (1910)

9) Finizio, B. : Monatschrift f. Kindheilk. 8, 505 (1909)

10) Hensel, G. : Zs. f. Kindheilk. Bd. 54,367(1933)

11) Wohlgemuth, J. : Biochem. Z. 9, 1 (1908)

12) Kuhn, R. : ann. d. chem. 443, 1 (1925)

13) Ohlsson, E. : Z. Physiol. Chem. 189, 17 (1930)

14) Willstätter, R.: Z. Physiol. Chem. 126, 141(1923)

15) Euler, H. V., O. S. : Z. Physiol. Chem. 112, 193 (1921)

16) Myrbäck, K. : Z. Physiol. Chem. 159,7 (1926)

17) 坂口媌一郎, 朝井勇宣編: 酵素 p. 151

18)梅本饬夫等：海科医学 14巻 1 号14 (1950)

19) Michaelis : 化学実験学第 2 部 p. 125 引用

20) 化学实験学 第 2 部 p. 666

21) Willstätter, R. u. G. S. : J. Biol. Chem. 54,617 (1922)

22）鈴木忠男：满洲雨科医学会雑誌 11 巻1号, 57(1932)

23) Simchen, H. : Arch. Kindheilk. 75, 6 (1925)

24) 中鉢不二郎：治療学雑誌 8卷, 9 号 999 (1935)

(金沢大学医学部 公鼻衛生学) 